\section{Friedrich Heinrich Jacobi}

\section{O Spinozinu nauku u pismima Mosesu Mendelssohnu

$\frac{\text { Spisi o sporu o božanskim }}{\text { stvarima i njihovoj objavi }}$

\section{Demetra, Zagreb 2013., prevela Darija Domić}

Na veliko zadovoljstvo akademskoj javnosti skrećem pozornost na znatan događaj za našu filozofijsku sredinu koji je nastupio u listopadu 2013. objavom ovih dvaju klasičnih djela njemačke filozofije u vrsnu prijevodu Darije Domić. Već sam se u prvim mjesecima objave ove knjige uporabom prvoga od njenih dvaju prijevoda u zajedničkome radu sa svojim studentima (seminar »Njemački prosvjetiteljski spor oko panteizma«) uvjerio da se ona može i treba preporučiti, s jedne strane kao nezaobilazno štivo za ozbiljan studij filozofije i kulture njemačkoga prosvjetiteljstva, njemačkoga idealizma i romantizma, a s druge kao veoma čitko i poticajno štivo za promišljanje i oživljivanje filozofijskih tema koje su s razlogom zaokupljale nemalen broj ondašnjih prvaka misli i pera.

Budući da se znatnost ovih djela i uloga njihova u povijesti filozofije, a onda i značenje toga da su u dobru prijevodu sada dostupni hrvatskomu čitateljstvu, ne može pravo shvatiti ne uzme li se u obzir kontekst njihova postanka i utjecaja, u ovome ću se prikazu najviše prostora njima posvetiti, $i$ to iscrpnije s obzirom na prvo, ranije i utjecajnije, a kraće s obzirom na drugo, mnogo kasnije djelo. Budući da je njihov pisac - Friedrich Heinrich Jacobi - više prigodno nego sustavno iznosio svoje za racionalno prosvjetiteljstvo duboko provokativne stavove, u novim ih djelima i novim izdanjima ranijih djela potom nadopunjavao i dorađivao, no građu ostavljao raspoređenu ne po logici stvari nego po redu prigodnoga nastajanja, ovaj prikaz uzimam i kao priliku da čitatelju olakšam tematsko snalaženje u njegovim djelima. Na koncu u prikazu dajem, povrh dužnoga priznanja i pohvale, i neke kritičke napomene uz naše izdanje tih djela hrvatski prijevod.

O Spinozinu nauku u pismima Mosesu Mendelssohnu (1785., $\left.{ }^{2} 1789 .,{ }^{3} 1816.\right)$ prvo je djelo koje je Jacobija, do tada poznatoga ugl. samo kao pisca nove sentimentalne književnosti u duhu Patnji mladoga Werthera, izvelo na glas filozofa ili čak nezaobilazna mislioca sentimentalista i fideista, a ujedno objavom svojega provokativnoga sadržaja širom otvorilo vrata - može se bez zadrške reći - najznatnijemu filozofijskomu događaju u Njemačkoj u doba prvih izdanja Kantovih kritika: tzv. sporu oko panteizma ili sporu oko Spinoze (njem. Pantheismusstreit ili SpinozaStreit). Može se ići tako daleko da se kaže da je i sama Kantova kritička filozofija, isprva slabo percipirana i recipirana, dobila zasluženu pozornost i ugled u očima šire učene javnosti tek zahvaljujući Reinholdovu prikazu (Pisma o Kantovoj filozofiji, 1786.-1787.) njene jedinstvene moći da pruži odgovore na pitanja koja su uslijed toga spora postala akutna, poglavito da pokaže kako um ipak dolazi do izvjesnosti u opstojnost Boga i besmrtnost duše, ali ne teorijski po nadosjetilnoj spoznaji, nego praktički po moralnoj vjeri.

Sam spor nastao je naizgled bezazleno. Jacobi je u proljeće 1783. saznao da se Mendelssohn, tada najčuvenija filozofska glava među berlinskim prosvjetiteljima, sprema napisati djelo o karakteru i spisima svojega preminuloga prijatelja i najbližega suradnika Gottholda Ephraima Lessinga, stoga ga je po pismu zajedničkoj poznanici Elise Reimarus dao upozoriti da se je čuveni teolog i dramatičar u zadnjim danima izjašnjavao kao spinozist. (Zanimljiva je okolnost da su Elise i njen brat Johann Albert Hinrich desetljeće ranije Lessingu predali u rukopisu pripremljena biblijskokritička i neortodoksna razmatranja svojega otca, čuvenoga deista Hermanna Samuela Reimarusa, a Lessing njihove najkontroverznije dijelove u navratima objavljivao kao Fragmente neimenovana Wolfenbüttelovca i time izazvao najveći njemački teološki spor 18. stoljeća, tzv. spor oko fragmenata, njem. Fragmentenstreit). U ono doba su Spinozini spisi bili konfiscirani kao bezbožn i po moral opasni, a spinozizam je općenito smatran ateizmom i fatalizmom, u Njemačkoj pak dodatno zbog velika utjecaja Wolffova prikaza i pobijanja spinozizma (Theologia naturalis, sv. II, §. 716). Takva su suda dobro bili svjesni i na Wolffovoj analizi spinozizma dalje gradili jednako tako wolffovski racionalist Mendelssohn kao i protuprosvjetiteljski nastrojen pijetist Jacobi, i zato vijest nije bila bezazlena. Da bi Lessing bio spinozist, Mendelssohnu je bilo nepoznato i strano, stoga je otvoreno zaželio podrobniji izvještaj i dodatno razjašnjenje o naravi spinozizma kojemu se je Lessing navodno priklonio. Jacobi je udovoljio njegovoj želji iscrpnim pismom, no ono je dovelo do još više nesporazuma neslaganja oko Lessingova i Spinozina panteizma, a potom i oko naravi prosvjetiteljskoga racionalizma, njegove previđane dublje veze sa spinozizmom, moći spekulativnoga uma i 
uloge vjere. Odužena prepiska tijekom idućih dviju godina rezultirala je porašću nepovjerenja i potom istodobnim iznošenjem predmeta spora pred javnost u dvama zasebnim spisima u rujnu 1785. Mendelssohnov novi plan bio je napisati metafizičku raspravu protiv panteizma (»onih kojima je sve jedno«) kojom bi se utvrdio status controversiae između njega i Jacobija, tj. priredio teren za razračun s Jacobijevim gledanjem na Lessingov i Spinozin panteizam i njihovu navodnu racionalnu nadmoć nad prosvjetiteljskim deizmom. Rasprava je izašla pod nazivom Morgenstunden oder Vorlesungen über das Dasein Gottes (Časovi jutarnje pouke ili predavanja o Božjoj opstojnosti; hrv. Kalenićev prijevod Jutarnji satovi ili predavanja o tubitku Boga izašao kao 2. sv. Mendelssohnovih Opera selecta, Demetra 2001.), u kojoj je, između ostaloga, u fiktivnome razgovoru s Lessingom predstavljen Lessingov "pročišćeni panteizam《, bezopasan po moral i religiju (Časovi jutarnje pouke, predavanja XIV i XV). Jacobi je pak, saznavši preko Hamanna za Mendelssohnov plan, nakanio preduhitriti Mendelssohna otkrivajući izvorni povod i puni kontekst spora objavom pisama i parafraza pisama iz njihove prepiske (uz uvodna i popratna objašnjenja), što je naš spis Über die Lehre des Spinoza in den Briefen an Herrn Moses Mendelssohn (kraće zvan i Jacobi's Spinoza-Büchlein, kako ga Matthias Claudius imenuje, a Fritz Mauthner pod tim nadimkom 1912. izdaje). Tim potezom Jacobi je htio izbjeći da ga se kao tumača Lessingova i Spinozina panteizma gurne u ulogu advocatus diaboli, da, iako teist, zastupa panteisteateiste. Duboko ogorčen Jacobijevom objavom prepiske bez njegove suglasnosti, Mendelssohn je replicirao spisom An die Freunde Lessings (Lessingovim prijateljima, siječanj 1786.), da bi potom njemu i njegovim brojnim no nemoćnim pristašama Jacobi zajedljivo duplicirao protuspisom Gegen Mendelssohns Beschuldigungen in dessen Schreiben an die Freunde Lessings (Protiv Mendelssohnovih optužaba u njegovu spisu Lessingovim prijateljima, travanj 1786.). Stari Mendelssohn uslijed žestine sporenja naglo je obolio (navodno se prehladivši noseći repliku u tiskaru) i umro već 6 . siječnja 1786., no zato su se drugi počeli uključivati u spor, zauzimati strane i prosuđivati o njenu predmetu. Tu su posebno vrijedne rasprave i prilozi mladoga pijetista Thomasa Wizenmanna (anonimni spis Resultate der Jacobischen und Mendelssohnschen Philosophie untersucht von einem Freiwilligen / Rezultati Jacobijeve i Mendelssohnove filozofije istraženi dragovoljcem, 1786.) Kanta (Was heißt: sich im Denken orientieren / Što znači orijentirati se u mišljenju - u izravnome nadovezivanju na Wizenmanna) te Herdera (Gott: einige Gespräche / Nekoliko razgovora o Bogu, 1787.)
Budući da je Jacobijevo djelo - sastavljeno od pisama ili parafraza pisama, raznih priloga i dodatnih bilježaka - već u prvome izdanju 1785. suvremenicima s pravom nalikovalo »rapsodiji« bez glave i repa, i budući da ga je Jacobi ktomu još dva puta znatno proširio pa i mijenjao u drugome (1789.) i trećem izdanju (1819.), teško je čitatelju isprva dobiti dobar pregled nad mnoštvom njegovih rasprava, dokumenata, bilježaka i uopće cjelina i vremenskih slojeva. Hrvatski prijevod prati suvremeno njemačko studijsko izdanje koje je 2000. priredila Marion Lauschke na osnovi kritičkoga izdanja Klausa Hammachera i Irmgard-Marije Piske (1998., Meiner). Po njem naš hrvatski prijevod dijeli spis na:

1) sve dijelove koji su sadržani u prvome izdanju uz dodatke i preinake na te dijelove u drugome i trećem izdanju u podnožnim bilješkama (označeno redom kao $\mathrm{D}_{2} \mathrm{i}_{\mathrm{D}_{3}}$ ) - str. 1-98,

2) proširenja drugoga izdanja (novi predgovor te čak devet Jacobijevih priloga, od kojih je deveti uklopljen u novi predgovor) - str. 99-196,

3) proširenja trećega izdanja (samo novi, ali opsežan predgovor) - str. 197-214.

No, da čitatelj dobije uvid u cjeline unutar Jacobijeva višekrat upotpunjavanoga djela, potrebno je upoznati točnu povijest nastanka djela u svim trima izdanjima, koje zato kratko ali iscrpno opisuje »Uredničko izvješće« na str. 224-231.

Veoma su korisne i uredničke »Napomene« koje donese podatke o spominjanim spisima i odgovarajućim mjestima u njihovim današnjim standardnim izdanjima, zatim osnovne podatke o manje poznatim ljudima, prijevode svih navoda s drugih jezika i katkad pune navode mjesta tek spomenutih u tekstu $-s t r$. 233-247.

Na koncu, na »Popisu literature« svi su spisi koji se spominju u Jacobijevu tekstu ili u »Napomenama«, a koji odaju dojam velike širine i raznolikosti (grčkih, latinskih, francuskih, njemačkih i engleskih) rasprava koje je Jacobi rado citirao i koje su kao svjedoci »prizvane« u spor oko panteizma - str. 249-258.

Međutim, za pravi studij ili rad u seminaru, Jacobijevo djelo se može razdijeliti na ove smislene i vremenski poredane sadržajne cjeline:

1) Prvo i daleko najzapaženije Jacobijevo pismo Mendelssohnu (4. 11. 1783.). U njem Jacobi opširno prikazuje svoje neobične razgovore s Lessingom u Wolfenbüttelu, Braunschweigu i kod Gleima u Halberstadtu u srpnju i kolovozu 1780 ., kada je Jacobiju bilo 37, a Lesssingu 51 godina. Do toga je došlo ovako. Jacobi 
1779. Lessingu šalje svoj roman Woldemar, a Lessing mu zauzvrat šalje svojega Nathana mudroga (18. 5.) s nekoliko prijateljskih i toplih redaka zahvale na »poučnome i čuvstvenome satu « koji mu je djelo priredilo (radi se o veoma sentimentalnoj i didaktičkoj književnosti koja je i Goetheu, piscu Patnja mladoga Werthera, bila pretjerana; Jacobi pak 1781., u dorađenome izdanju Allwilla, tvrdi da mu je Allwill priskrbio Lessingovo prijateljstvo). Ne skrivajući radost, Jacobi mu pismom 20. 8. s oduševljenjem najavljuje posjet u Wolfenbüttel na proljeće, kako bi u njem »prizvao duhove nekoliko vidjelaca i naveo ih da progovore« jer njemu »nedovoljno odgovaraju«. Lessing u lipnju ljubazno odobrava posjet i dopušta da potraje više dana, a Jacobi mu stiže 5 . srpnja uvečer te otpočinju razgovori »o moralnim i nemoralnim osobama, ateistima, deistima i kršćanima«. Ujutro Jacobi Lessingu daje na čitanje (Goetheovu) pjesmu »Prometheus «, a Lessing mu otkriva da se, kao u toj pjesmi Promethēj, tako ni on više ne miri s ortodoksnim predodžbama o božanstvu, nego si ga predočuje kao $\tilde{\varepsilon} v \kappa \alpha i \pi \tilde{\alpha} v$ (»jedno i sve« - što je onda kao svoju panteističku krilaticu zapisao na Gleimovu vrtnu kućicu i drugdje, a Jacobi protumačio tako da si Lessing osobno božanstvo predočuje kao dušu svemira). Na pitanje o njegovu slaganju sa Spinozom, Lessing hipotetički odgovara: »Trebam li se nazvati po nekome, ne znam po kome drugome«. U isprekidano prikazanim razgovorima, Jacobi i Lessing u zabavnu tonu i s neprikrivenim divljenjem razlažu racionalnu snagu i dosljednost Spinozine panteističke i determinističke filozofije, na koju Lessing naizgled hoće svesti i Leibnizovu (što Jacobi dopušta po pitanju duše i slobode no ne i Božje transcendencije), dok Jacobi od njena prirodnoga objašnjenja natprirodna i posljedičnoga »ateizma i fatalizma« traži spas čineći salto mortale u vjeru, tj. u prihvaćanje da se stanovite istine ne mogu racionalno razlagati, nego ih trebamo uzeti kako ih nalazimo (dubinski osjećamo), a takvo je primjerice njegovo živo uvjerenje da doista čini što misli, umjesto da (po Spinozi) samo misli što čini jer navodno nema svršnih uzroka. Lessinga su Jacobijevi pokušaji zabavljali, no ustrajao je na naturalizmu u teologiji, a u psihologiji bio sklon vjerovati, kako uostalom svjedoči kraj njegova Odgoja ljudskoga roda (§. 94.-100.), u reinkarnaciju s osobnošću u smjeru sve većega savršenstva, zbog čega mu je bila bliska Bonnetova Palingénésie philosophique (1769.). Prilično savjesnim i iscrpnim prikazom njihovih razgovora Jacobi je htio ukloniti svaku sumnju da je Lessing vjerovao $\mathrm{u}$ transcendentni uzrok svijeta, $\mathrm{tj}$. da nije bio spinozist ili da se je čak samo ironijom zabavljao na račun lakovjerna religioznoga entuzijasta Jacobija, kakvu je stavu Mendelssohn prije ovoga izvješća bio sklon, a neki Lessingovi tumači ga i danas gaje (v. H. B. Nisbet, 2008., Lessing. His Life, Works, and Thought, str. 633 i d.). Spekulativno tumačenje otajstva Božje trojednosti u §. 73. Odgoja ljudskoga roda, Jacobiju poznat kao predmet razilaženja Lessinga i Mendelssohna, Jacobi je tako mogao protumačiti spinozistički: da bi Bog imao potpunu predodžbu o sebi, on se, po Lessingu, mora u zbilji udvostručiti u »Sina kojega odvijeka rađa«, tj. biti tako apsolutan da ne isključuje unutarnju množinu, nego se štoviše dijeli na Otca i Sina iliti, kako Jacobi u skladu sa Spinozom tumači: natura naturans i natura naturata. - str. 13-33.

2) Mendelssohnove opaske na to Jacobijevo pismo (1. 8. 1784.), koje Jacobi izdaje tek u drugome izdanju djela 1789. (nakon što ih Mendelssohn objavljuje u spisu Lessingovim prijateljima 1786.). U prijevodu Darije Domić ovaj dio nosi nesretan naslov »Sjećanja na gospodina Jacobija«, iako se tu ne radi ni o kakvim uspomenama na čovjeka F. H. Jacobija, nego o Mendelssohnovim komentarima ili opaskama na Jacobijevo pismo ili o primjedbama upućenima Jacobiju (Erinnerungen an Herrn Jacobi). One odaju nelagodu i gubitak strpljenja zbog mnogih mu nerazumljivih, međusobno nesuvislih ili neprihvatljivih mjesta iz Jacobijeva pisma koja tumače Spinozinu filozofiju ili Jacobijev stav prema panteizmu. Primjedbe vrve što pravim što retoričkim pitanjima te pokušajima da se nesuvislosti objasne na razumljiv način ili da se ukaže na teškoće. - Uistinu je Mendelssohn zarana simpatizirao sa Spinozom, kako s njegovom osobnom sudbinom Židova izopćenika, tako i s njegovom filozofijom, i proglasio ga pravim otkrivačem Leibnizove harmoniae praestabilitae (Razgovori, 1755.). Zanimljivo, njegov izvod je Jacobi prihvatio (prijevod D. D., str. 19), a Lessing smatrao sofizmom (pismo Mendelssohnu 17. 4. 1763.). Mendelssohn se nije slagao s Jacobijem da bi Spinoza bio ateist, kako ga je Pierre Bayle tumačio (prev. D. D., str. 11), a još manje njegov Lessing takav spinozist. Jacobijev salto mortale za Mendelssohna je »spasonosni put naravi« koji on tumači kao orijentaciju zdravim razumom (bon sens) kada spekulacija zastrani u ateizam 
ili fatalizam, i koji sam preporučuje ( $\breve{C} a$ sovi jutarnje pouke, predavanje $\mathrm{X}$ ). Ovu poredbu njihovih rješenja za spekulativne zastrane Wizenmann će u spomenutoj raspravi uzdići do jednačenja na štetu tobože obrazlažućega i samostalnoga uma, na što će, na inzistiranje berlinskih prosvjetitelja, Kant odgovoriti u obranu uma kao konačnoga sudišta također gore spomenutom raspravom, a ona će ovu dvojicu uvesti u zaseban nastavak rasprave, čiji je zadnji komad sastavni dio Kritike praktičkoga uma (v. Lj. F. Ježić, »O umskoj potrebi za vjerom u božju opstojnost po raspravi Wizenmanna i Kanta«, Logos. Casopis za filozofiju i religiju (2/2013), str. 81-102). - str. 120-126.

3) Prijepis pisma gospodinu Hemsterhuisu u Haagu (7. 8. 1784.). U pismu se prikazuje Jacobijev izmišljeni razgovor sa Spinozom kao prilog Jacobijevoj raspravi s Hemsterhuisom i njegovim djelom Aristée ili o božanstvu (1779.). Jacobi prijepis toga pisma šalje Mendelssohnu 5. 9. 1784. kao privremeni odgovor na opaske / »Sjećanja«, tj. kao pripomoć Mendelssohnu da bolje razumije njegove poglede na Spinozu. - str. 41-51.

4) Jacobijev prikaz Spinozine filozofije $u$ XLIV postavke (str. 55-72) te odgovor na Mendelssohnove opaske / »sjećanja« (str. 73-76) u pismu Mendelssohnu 21. 4. 1785. U odgovoru stoji da uvjerenje iz umskih razloga mora doći iz vjere (u širem pojmu smatranja čega istinitim), i svoju snagu iz nje primati. Njegova posredna izvjesnost pretpostavlja njenu neposrednu izvjesnost. Tako na vjeru prihvaćamo opstojnost svojega tijela, ali i drugih tijela i misaonih bića, a preko opažanja dobivamo objavu prirode koja nas sili da $\mathrm{u}$ izvanjske predmete vjerujemo kao u zbiljske (kako Jacobi može izvoditi na tragu s jedne strane Hamannova tumačenja Humeova pojma belief, a s druge Reidove filozofije naravnoga razuma - common sense; o središnjoj ulozi vjerovanja kao osjećaja kod Humea i njegovu utjecaju na Hamanna i Jacobija v. upućen prikaz u M. Globačnik, Izazov skepticizma, 2016., poseb. pogl. 2.4. i 4.3.). - Valja ovdje usput napomenuti da će ova Jacobijeva proširena uporaba pojma vjere izazvati mnogo negodovanja prosvjetitelja, tako i recenzenta ovoga djela u čuvenome glasilu kantovaca Allgemeine Litteratur-Zeitung, zbog čega će Jacobi takvu uporabu pojma vjere braniti u spisu David Hume o vjeri (1787.). Mnoge će ovi i naredni Jacobijevi izvodi zgroziti ili potaknuti da se zamisle, a niz njih i da ugrade jacobijevski pristup u svoje promišljanje ovih pitanja, zbog čega će Hegel još u Enciklopediji filozofijskih znanosti ( ${ }^{2} 1827$.) naširoko izvoditi kritiku Jacobijeva stajališta »neposrednoga znanja« kao »trećega stava mišljenja prema objektivitetu « (§ 61.-78.). A Kant će u predgovoru novoga izdanja Kritike čistoga uma ( ${ }^{2} 1787$.) jacobijevski pristup idealističkomu problemu opstojnosti stvari izvan nas nazvati »skandalom filozofije i općeljudskoga uma« (B XXXVIII i d.), umjesto kojega preporuča da se prihvati njegovo novo pobijanje idealizma i zasnivanje realiteta izvanjskoga zora.

5) Jacobijevi stavovi o Spinozi, demonstrativnoj metodi i vjeri u filozofiji sabrani u sedam postavaka (str. 78-82), kao i njihovo tumačenje $\mathrm{u}$ nenaslovljenome "pogovoru" izdanju Jacobijevih pisama Mendelssohnu o Spinozinoj nauci (str. 84-98), sasvim prožetome duhom Jacobijeva sentimentalnoga teizma, s kratkim biblijskim izrazima i zaključnim navodom iz »anđeoski čistih usta« naivno pobožna Lavatera (inače poznatoga po neumjesnu i neuspješnu javnu izazovu Mendelssohnu 1770. da ili obori kršćanstvo ili se obrati sa židovstva). Oni stavovi su kratke, odrješite i duboko provokativne Jacobijeve teze koje su posebno uzbudile njemačke prosvjetiteljske duhove. Jer tvrde da je leibnizovsko-wolffovska filozofija fatalistična koliko i spinozizam, a ovaj da je ateizam, i uopće da »svaki put demonstracije vodi u fatalizam«, dok je pak »element svake čovjekove spoznaje i djelotvornosti vjera«. Argumentativno je slabiji, ali književno dojmljiviji Jacobijev »pogovor«, koji uostalom anticipativno za Hegela i Marxa sadrži tezu da svako doba ima svoju vlastitu istinu u sadržaju svojega iskustva te vlastitu živu filozofiju jer ona tek izražuje prevladajući način kako ljudi u tome dobu djeluju, nakon što ovaj uznapreduje do predodžbe. Način mišljenja ljudi izvire iz njihove povijesti, a ne obrnuto. No neočekivan je Jacobijev obrat: da biste ispravili način mišljenja ili filozofiju ljudi, trebate ispraviti njihovu povijest, tj. njihov način života, jer razum sam nema svjetlost i razvija se kroz volju kao iskru božanske svjetlosti u nama. Tek će vršenjem vrline ljudi upoznati njenu ideju, a božanskim životom osvijestiti Boga i znati da su u njem (str. 75, usp. I Iv 2,3-6).

Vremenski slijede još samo predgovori drugih dvaju izdanja i devet priloga drugoga izdanja (1789.), koji se naravlju i znatnošću veoma razlikuju (povijesnofilozofijski su za njemački idealizam ključni VI, VII i »IX«) i o kojima polaže račun u Predgovoru. To su: 
6) Jacobijeva utjecajna raspravica $» \mathrm{O}$ čovjekovoj slobodi« u LII postavke unutar Jacobijeva »Predgovora" drugomu izdanju Pisama (1789.), njegov tako reći »Deveti prilog«, str. 109-117.

7) Izvadak iz spisa De la causa, principio, et Uno Giordana Bruna kao »Prilog I «, kojim Jacobi, skupa s prikazom Spinozine filozofije, želi dati »summu filozofije $\tilde{\varepsilon} v$ $\kappa \alpha i \pi \tilde{\alpha} v \ll u$ jednoj knjizi. Bruno Jacobiju pritom utjelovljuje »duh starih « (panteista), stoga se u ovoj knjizi sam ne osvrće posebno na antičke zastupnike svejednosti (Elejci, Hērakleit, Plōtin), nego tek na kasniju »kabbalističku filozofiju« i njene »najbolje tumače« (str. 79): Franciscus Mercurius van Helmont i Johann Georg Wachter. Čini se da je Wachterovo povezivanje Spinoze i Qabbāle utjecalo na Jacobijevo razumijevanje i svakako izlaganje Spinoze (usp. str. 15: Spinozin Bog kao 'ên sôf ili imanentni uzrok svijeta).

8) Raspravica o ateizmu Fransa Hemsterhuisa (Prilog II) nastala na Jacobijev poticaj (1787.). Uvelike zahvaljujući Jacobiju, Hemsterhuisovi filozofijski dijalozi i stajalište blisko Jacobijevu postali su osjetno utjecajniji i prisutniji u narednim njemačkim raspravama (posebno Schelling i romantičari) nego u nizozemskima ili francuskima.

9) Prilog IV i V kao polemika s Herderom koji se u Nekoliko razgovora o Bogu mnogo osvrće na Jacobijev spis i drugačije tumači zabilježene Lessingove izjave, a simpatetičan je (svojemu osebujnomu vitalističkomu) Spinozi.

10) Jacobijeva studiozna poredba sličnosti i razlika Spinozina i Leibnizova sustava kao »Prilog VI« (str. 166-179).

11) Jacobijeva »prirodna povijest spekulativne filozofije« ili »o postanku i svrsi spinozizma« kao »Prilog VII«, str. 180 193. Tu se pokazuje zašto je bezuman racionalistički pothvat potrage za uvjetima neuvjetovana (v. najavu priloga na str. 105).

12) »Uvodno izvješće« (Predgovor) trećemu izdanju (1819.) koje daje koristan osvrt na davno objavljeno djelo i vlastiti životni filozofski stav, uz mnogo prikrivene polemike s Friedrichom Schlegelom (nadmenim recenzentom njegova autobiografski obilježenoga Woldemara i kritičarem njegove nefilozofske »glave srasle sa srcem «) pa i sa Schellingovim uzdizanjem prirode i panteističkim poimanjem božanstva.

O božanskim stvarima i njihovoj objavi (Von den göttlichen Dingen und ihrer Offenbarung, ${ }^{1} 1811 .,{ }^{2} 1822$.) još je jedan Jacobijev po nastanku prigodnički spis, jer je izrastao iz recenzije sveska VI Sabranih djela Jacobijeva staroga prijatelja Matthiasa Claudiusa (»Glasnika iz Wandsbecka)« iz 1798., no također još jedan Jacobijev kontroverzistički spis, jer se u njegovoj drugoj polovini naširoko razračunava sa Schellingovom panteističkom filozofijom prirode i filozofijom identiteta, suptilno ih optužujući za ateizam. On u hrvatskome prijevodu dolazi kao dodatak uza spis O Spinozinoj nauci (na str. 263-376), a ispred »Kazala imena« (str. 379-382) za oba spisa. No, iako ovdje uzet kao dodatak, radi se zapravo o spisu koji ima vlastiti zahtjevan kontekst i povijest nastanka dva desetljeća nakon spisa $O$ Spinozinoj nauci, također složenu strukturu (predgovor, isprekidani glavni dio i četiri priloga), te osebujnu povijest utjecaja, dapače vlastiti učeni spor koji je polučio, a koji stručna literatura naziva sporom oko teizma (njem. Theismusstreit) ili sporom oko božanskih stvari i njihove objave. Zato bi zaslužio zaseban prikaz, a koji ovdje mora biti kraći nego što spis, njegova pozadina i posljedica traže. Tekst spisa preveden je prema trećem svesku cjelovitoga izdanja Jacobijevih djela (Werke) (ur. Klaus Hammacher i Walter Jaeschke) s naslovom Schriften zum Streit um die göttlichen Dinge und ihre Offenbarung, no bez Jacobijeva predgovora (»Uvodnoga izvješća «) drugomu izdanju (1816.) i bez predgovora trećemu svesku Jacobijevih sabranih djela (Werke), u kojem se je nalazilo drugo izdanje spisa o božanskim stvarima. (Prvi od tih dvaju neprevedenih predgovora se osvrće na Schellingovu bijesnu reakciju i poziva se na brojne recenzije u Jacobijevu obranu, a drugi razjašnjava nesporazume u Schlegelovoj recenziji Jacobijeva djela, poglavito ono da Jacobi daje prednost nutarnjoj ili moralnoj objavi pred povijesnom kršćanskom koja je tek vanjska pripomoć za prvu.) Budući da se u hrvatskome izdanju za spis ne daje nikakvo uredničko ili prevoditeljevo izvješće ni uvod, ovdje treba ukratko ocrtati njegov konteks (za koji rabim uredničko izvješće njemačkoga izdanja od kojega prijevod polazi).

Obojica, Jacobi i Schelling sele se u München, prvi 1805. kao član Bavarske akademije znanosti i uskoro njen predsjednik (1807.1812.), drugi 1806. kada ulazi u bavarsku državnu službu i postaje član Akademije. Iako pod stalnom prijetnjom da napetosti i razlike između staroga teista i mladoga panteista buknu, obojica nastoje stvoriti kolegijalan i prijateljski odnos, Schelling čak katkada objeduje kod Jacobija. No to biva kratka vijeka. Schellingov govor u Akademiji o odnosu likovnih umjetnosti prema prirodi (na kraljev imendan 12. 10. 1807.) Jacobija, kako ovaj piše Friesu 26. 11., »neuzdrživo nagoni« da 
se posveti razlaganju Schellingove filozofije čija ga prijevarna uporaba jezika razjaruje, a čiji Bog zapravo ne stvara ništo doli vrijeme (usp. prijevod D. D., str. 346). 1809. Schelling $\mathrm{u} »$ Filozofskim spisima« objavljuje taj govor skupa s trima ranijim raspravama te jednom novom o biti ljudske slobode, koja bi trebala ispraviti Schlegelov sud (O jeziku $i$ mudrosti Indijaca, 1808.) da panteizam, za koji je sve jedno, nužno ukida razliku između dobra i zla. U to doba Jacobi nastavlja davno prekinuti rad na raspravi o božanskoj objavi povodom recenzije Claudiusova djela. Schellingovo djelo daje mu povod da drugi dio rukopisa, iskorišten i objavljen dijelom u Otvorenome pismu Fichteu, dijelom u raspravi $O$ pothvatu kriticizma da um privede razumu, iznova napiše kao »razmatranja o religioznom realizmu i idealizmu, slovu i duhu, umskoj objavi i pozitivnome nauku«, no zapravo da ga iskoristi kao mjesto za razračun sa Schellingovim dosljednim ali pogubnim dovršenjem Kantove i Fichteove »ideal-materijalističke« filozofije (u prijevodu Darije Domić str. 324-376, uključno dakle s trima prilozima: A, B i C). Uz povremene anticipacije polemike koja otvoreno slijedi u drugome dijelu spisa, tomu prethode izvorna i dorađena razmatranja uz recenziju Claudiusova djela (str. 293-324) te kao zaseban uvod pretisak Jacobijeve rasprave $O$ jednom Lichtenbergovu proročanstvu iz 1802. (str. 269-289).

Lichtenbergovo proročanstvo koje uvodi i daje ton djelu glasi: "Svijet će nam se još toliko istančati da će biti jednako smiješno vjerovati u nekoga Boga kao danas u sablasti. (...) A tada ćemo - i to će biti kraj - vjerovati samo u sablasti. Mi sami bit ćemo poput Boga. Znat ćemo: bitak i biće posvuda jest može biti samo - sablast.« Iako se to prvotno Jacobiju moglo odnositi na Fichtea, kojega je u sporu oko ateizma nazvao »istinitim mesijom spekulativnoga uma«, kojemu je Kant tek prethodnik kao »königsberški krstitelj«, sada istu ocjenu nihilizma još u većoj mjeri može i želi pripisati Schellingu jer on sam svijet spekulativno i prirodno izvodi iz Boga kao supstancijalne indiferencije subjekta i objekta ili »znanja i bitka«. Nasuprot tomu, Jacobi otvoreno ispovijeda vjeru u kršćanskoga Boga kao čovjeku nepojmljiva ali iznutra i izvana objavljivana transcendentnoga uzroka svijeta. Claudius, čije djelo recenzira, pritom mu pomaže jer piše da se u čovjeku nalazi ne samo »nešto drugo nego u cijeloj prirodi«, nego i da je to drugo "višse od prirode i iznad nje (str. 296). To više, po Jacobiju, čovjeku omogućuje da se uzdigne iznad prirode, tako reći do platonovskih ideja, i nametne joj zakone pravednosti i mudrosti, ljepote i dobrote, a ujedno osvijesti jedinoga Boga, svemoć »koja nije samo sveopća sila neke slijepe prirodne ili svjetske duše, koja se pokorava nužnosti (zapravo samo izmaštanoj sablasti same nužnosti), nego je volja nekoga tko hoće, koji znajući i sa slobodom dopušta iz ljubavi da nastaje sve što se raduje postojanju.« (str. 297)

No središnja, kratka i bistra analiza razvoja i značenja njemačke idealističke filozofije od Kanta do Schellinga nalazi se u drugome dijelu spisa. Kant je još otvoreno tvrdio da ga zanima, u oprjeci s deističkim uzrokom svijeta teistički Tvorac svijeta (Kritika čistoga uma, B 659-660). Kant je pokazao da su svi spekulativni dokazi za opstojnost živoga Boga (kao i za besmrtnost duše ili apsolutno samoodređenje volje) nedostatni, no taj gubitak teorijskih dokaza nadomjestio je postulatima praktičkoga uma i čistom umskom vjerom. Međutim, već se »prvo dijete kritičke filozofije«, Fichteovo znanstvoslovlje oslobodilo tih postulata i uopće Boga kao transcendentnoga uzroka moralnoga poretka po Kantovoj moralnoj teologiji, jer je sada sam živi i djelatni moralni poredak postao Bogom. Taj je Bog bez svijesti i osobnosti jer bi ga one učinile konačnim i ograničenim. Takve tvrdnje Fichtea su stajale profesorskoga mjesta $u$ Jeni. No, nastavlja Jacobi, potom je »druga kći kritičke filozofije« potpuno ukinula »razlikovanje prirodne i moralne filozofije, nužnosti i slobode, i bez oklijevanja proglasila iznad prirode nema ničega, i ona jedina jest.« (str. 327). Schellingova bi polazišna nakana po tome bila razriješiti svaki dualizam u jednome, a glavno sredstvo oslobađanje prirode od natprirodna, ili svijeta od uzroka izvan i iznad njega. U tome smislu Jacobi dopušta Schellingu da njegov sustav doista oživljuje najstariju filozofiju, jer je rana grčka misao naturalistička i, kako Aristotel tumači, do Anaxagore um kao uzrok nije odijelila od prvotne tvari iz koje sve proizlazi. Naturalizmu kao prvotnoj filozofiji zato teizam prethodi jedino kao vjera ili predznanstveno samouvjerenje zdravoga razuma. No, je li to bila Kantova namjera? Jacobiju se otvara prilika da Kanta suprotstavi Schellingu. Jer, iako je filozofija sveopće jednosti dosljedna posljedica znanstvoslovlja, a ovo kriticizma ipak je duh Kantove filozofije suprotan duhu Schellingove koliko i platonizam spinozizmu (str. 331-332)! Kantu su Bog, duša i sloboda ipak ideje kao i Platonu, za kojega, iako nadilaze svako iskustvo, ipak »imaju svoj realitet i nipošto nisu utvare« (Kritika čistoga uma B 370). Schelling je pak od ranih spisa za svoj uzor i nadahnuće priznavao Spinozu (ironično - upravo pod utjecajem Jacobijevih objavljenih pisama Mendelssohnu). Karakterizaciju »obrnutoga (ili preobraženoga) spinozizma«, 
koju je najprvo kao »subjektivni spinozizam« za Fichteov sustav smislio i usmeno širio njegov nevjerni mladenački prijatelj Weißhuhn (Schillerovo pismo Erhardu 26. 10. 1794.), a potom ga posredstvom Baggesena Jacobi kao »obrnuti spinozizam « objavio u čuvenome Otvorenome pismu Fichteu (1799.), sada Jacobi pridaje Schellingovu idealmaterijalizmu. Ali to ne vrijedi za Kanta, i zato Jacobi drugačije, neidealističko tumačenje Kanta izvodi uz pomoć djela jacobijevskih Kantovih nastavljača: Bouterwerkove Spomenice Immanuelu Kantu (1805.) i Friesove Nove kritike uma (1807.). Pobliže vidjeti taj zanimljiv izvod ostavljam čitatelju, a samo kao meku iznosim da je za Jacobija Kantov središnji uvid to da predmete poimamo samo ukoliko ih možemo proizvesti u mislima (kao u geometriji), tako reći transsupstancijalizirati ih u matematička i logička bića. To, međutim, ne dopuštaju predmeti metafizike: Bog, sloboda i besmrtnost, stoga znanost po pitanju njihove zbilje mora ostati neutralna. Time Kant oživljuje uvide Vica (načelo verum-factum) i Pascala (usp. Lj. F. Ježić, »Viewing Vico within German Idealism. On Jacobi's Comparison of Vico with Kant and with Schelling's System of Identity«, Synthesis philosophica (2/2015), str. 243-250).

Ali njegova utjecaja radi spominjem glavni žalac koji Jacobi Schellingu upire povrh optužbe za spinozizam, tj. za naturalistički ateizam, fatalizam i idealmaterijalizam. Žalac se sastoji u tvrdnji da Schellingov naturalizam »ne smije ni poželjeti govoriti o Bogu i božanskim stvarima, o slobodi, o ćudorednome dobru i zlu, o pravoj moralnosti; jer prema njegovu najdubljem uvjerenju te stvari nisu, govoreći o njima on kaže ono što zapravo ne misli. Tko čini nešto takvo, taj govori laži.« (str. 344). Pozivajući se na tome mjestu na Schlegelov spis O jeziku $i$ mudrosti Indijaca Jacobi oduzima vrijednost svemu naporu protiv tvrdnja toga spisa koji je Schelling u međuvremenu uložio u svoj spis o slobodi (1809.).

Još nešto o utjecaju spisa $O$ božanskim stvarima i njihovoj objavi. Schelling je spis doživio kao dobrodošlu priliku za »otvoreni rat«, kako piše u pismu gospodinu von Georgii 12. 1. 1812. A njegov je odgovor Jacobiju, sastavljen u roku od mjesec dana na prijelazu u 1812., ujedno zadnji Schellingov spis prije duge i rijetko publikacijama prekidane šutnje do kraja života. On nosi naslov Spomenica F. W. Schellinga spisu o božanskim stvarima itd. gospodina Friedricha Heinricha Jacobija $i$ u njem mu iznesenoj optužbi namjerno obmanjujućega $i$ laži govorećega ateizma (1812.). Ogorčen i zajedljiv ton ovoga spisa Schellingu je priskrbio malo pristaša, ali su se zato pomoću recenzija protiv njega digli Bouterwerk, Fries i nekoliko neidentificiranih, a Fries ktomu i zasebnom monografijom O načinu i umijeću njemačke filozofije. Glas za Friedricha Heinricha Jacobija $i$ protiv W. F. J. Schellinga (1812.). U taj su se spor oko teizma razni pisci uključili i na njega osvrtali, između ostalih Henrich Steffens (u čuvenoj autobiografiji) i višekrat Goethe, a nešto kasnije i Reinhold (Staro pitanje: što je istina?, 1820.) i konačno Schlegel (recenzija Jacobijevih sabranih Djela, 1822.). Svi znatni prilozi tomu sporu sabrani su 1994. u knjizi Transzendentalphilosophie und spekulative Theologie (ur. W. Jaeschke). Kako se pozicije Jacobija i Schellinga razlikuju te da ovaj njihov spor nije doprinio razvitku poimanja njegova predmeta, u nas je prikazao Damir Barbarić (»Prijepor Jacobija i Schellinga oko panteizma«, Godišnjak za filozofiju 2 (2004), str. 116-136).

Treba napomenuti da smo do sada od Jacobijeva djela u prijevodu imali tek neke izvatke iz gornjega spisa $O$ Spinozinoj nauci te skoro pa cjelovitu raspravicu $O$ transcendentalnome idealizmu, koju Jacobi prilaže kao dodatak svojemu spisu David Hume o vjeri (1787.), a u kojoj na veoma utjecajan način pokušava pokazati, suprotno ranim kantovcima, da sam Kantov sustav, razrađen $\mathrm{u}$ transcendentalnoj analitici i dijalektici, uklanja svoju pretpostavku na osjetilnost navodno djelatnih a opet posve nespoznatljivih stvari o sebi, zbog čega dosljedni transcendentalni idealist »treba imati hrabrosti da zastupa najsnažniji idealizam koji se je ikada naučavao«. Te je prijevode načinio Kiril Miladinov za hrestomatiju $F i$ lozofija njemačkog idealizma (ur. Damir Barbarić, Školska knjiga 1998.). Izvatke iz obaju Jacobijeva djela u sporu oko panteizma pisac ovih redaka preveo je za čitanku u svojem seminaru o tome sporu. Čitanka bi mogla, jednom dovršena, za neko vrijeme izaći u tisku. Od ostatka Jacobijeva djela trebalo bi najprvo napraviti prijevod onodobno najtraženijega i najutjecajnijega Jacobijeva spisa David Hume o vjeri ili idealizam i realizam (1787.), a po mogućnosti i Jacobijeva Otvorenoga pisma Fichteu (An Fichte, 1799.) u jeku spora oko (Fichteova i Forbergova) ateizma (pregledan prikaz toga pisma nalazi se na hrvatskome i u monografiji: Lj. F. Ježić, Razvoj Fichteova jenskoga sustava itd., str. 119-122). Za povijest njemačke književnosti ili ispreplitanja nje s filozofijom posebno su zanimljivi Jacobijevi filozofijski romani Allwill i Woldemar, koji su s jedne strane vezani uz Goetheov lik (Allwill) i djelo te Jacobijevu drugačiju osjećajnu i moralnu nastrojenost (Woldemar), a s druge zanimljivi jer Jacobi tu provodi svoju "zadaću istraživača» (v. O Spinozinoj nauci, 
str. 22) da (raz)otkriva i objavljuje opstanak (Dasein) (umjesto njegova obrazlaganja i objašnjavanja) te jer iznosi kritiku kantovskoga idealizma (koji zastupa lik Clerdon) sa stajališta života (koje zastupaju Cläre i Allwill).

U nedostatke inače vrsna i uzorna prijevoda Darije Domić može se ubrojiti izostanak oznaka paginacije izvornika, pogotovo važno kod prvoga, drugoga i/ili trećega izdanja spisa O Spinozinu nauku, jer se brojne referencije (primjerice u osmerima prilozima, a u odnosu na glavni tekst) upravo na njih odnose, no kako u hrv. prijevodu nisu označene, čitatelj ih pješke mora tražiti. Nedostatak koji se s vremena na vrijeme osjeti jest pomalo mehanički karakter prevođenja, pa se zbog neobraćanja pažnje na kontekst ili pravi i puni smisao on u doslovnu prijevodu čak zastre ili izgubi. Povrh toga, pojavi se neka prevoditeljska dosjetka koja prekine inače dosljedno prevođenje nekoga nazivka. Tako se je $D a$ sein uglavno dosljedno prevodio kao »opstanak«, »opstojnost« ili »opstojanje«, a Sein kao »bitak«, što je oboje dakako dobro, ali na str. 28 (i opet 125 i 180), u rečenici u kojoj se oboje javljaju, Dasein odjednom postaje »tubitak«, pa Jacobi za Spinozina Boga kaže da je »čisti princip bitka u svem tubitku«. Na str. 22 pak obratno Dasein postaje »bitak«, pa Jacobi kaže da je »najveća zasluga istraživača da razotkriva bitak i da ga objavljuje«, što bi u nekome heideggerovskome djelu moglo stajati, ali ovdje jednako malo ili još manje spada nego u Ladanov prijevod Metafizike gdje se kao predmet prve filozofije u knjizi $\Gamma$ odjednom javlja »bitak kao bitak« ( $\tau \grave{o}$ ôv $\tilde{\eta}$ óv »suće kao suće«, ili po Ladanovu nazivlju: »biće kao biće«), jer Jacobi doista misli na (ljudski) opstanak ili egzistenciju (»čovječanstvo kakvo jest«) koju onda prikazuje ili »razotkriva« u svojim filozofijskim romanima. No takvi su propusti ipak malobrojni, a prijevodi veoma upotrjebljivi i visoko preporučljivi i svima onima koji hoće upoznati Jacobijevo djelo bez poznavanja njemačkoga izvornika. Ovom se je knjigom sustavno i kvalitetno počelo prevoditi »obada njemačkoga idealizma«, kojemu već Hegelova povijest filozofije s pravom posvećuje zasebno poglavlje u »Najnovijoj njemačkoj filozofiji« - uz bok samo poglavljima o Kantu, Fichteu i Schellingu. A poznavanje ovih Jacobijevih djela također nam otvara put $\mathrm{u}$ dublje razumijevanje čitavoga razdoblja i motiva razvoja njegove misaono zahtjevne, ali plodne i moćne filozofije.

\section{Ljudevit Fran Ježić}

doi: $\underline{10.21464 / f i 37214}$

\section{Peter Sloterdijk}

\section{Die schrecklichen Kinder der Neuzeit}

\section{Über das anti-genealogische Experiment der Moderne}

\section{Suhrkamp Verlag, Berlin 2014.}

Nakon 1983. godine kada je objavljena Kritika ciničkog uma, jedno od najprodavanijih filozofskih djela 20. stoljeća, Petera Sloterdijka gotovo da i ne treba dodatno predstavljati. Objavio je oko četrdesetak knjiga, a njegovo posljednje djelo, Die shrecklichen Kinder der Neuzeit slovi za jedno od njegovih najboljih, no ujedno i najpesimističnijih djela. Filozofsko djelo koje nailazi na svesrdno prihvaćanje, ali i surovu kritiku s obje strane političkog spektra, posebice u Njemačkoj.

Djelo je podijeljeno u osam poglavlja, redom: »Von Erbe, Sünde und Moderne«, »Die Permanente Flut. Über ein Bonmot der Madame Pompadour «, »Dasein im Hiatus oder: Das moderneFragen-Dreieck:DeMaistre-Tschernyschewski - Neitzsche«, »Dieser beunruhigende Überschuß an der Wirklichkeit Vorausgreifende Bemerkung zum Zivilisationsprozeß nach dem Bruch «, »Leçons d'histoire Sieben Episoden der Geschichte der Drift ins Bodenlose: 1973 bis 1944/1971«, »Das ÜberEs: Vom Stoff, aus dem Sukzessionen«, »Die große Freisetzung «, »Im Delta«.

Sloterdijk prvo poglavlje započinje svojevrsnom definicijom suvremenog čovjeka: »Čovjek je životinja kojoj morate pojasniti situaciju«; misao koja je ujedno nit vodilja samog djela. Biće koje, podigne li glavu i usmjeri pogled preko horizonta očitog, zapada u stanje nelagode i uznemirenosti (str. 9). Prvotne interpretacije čovjekovog stanja očituju se kroz pitanja o početku, cilju i smislu ljudske egzistencija. Kasnije, posebice u djelima romantičara, zapaža Sloterdijk, poimanje čovjeka zapada u mistifikaciju i ne razrješuje se sve do egzistencijalne filozofije. Egzistencijalistička filozofija započet će svoj proboj stavom da početke ne poznajemo, cilj je zamračen, a negdje između njih nalazi se svijetu izloženi čovjek. Biće koje je opterećeno nelagodom pri bitku-u-svijetu (In-der-WeltSein). Metafizički debakl koji će se početi rješavati tek u filozofiji Aurelija Augustina, no bez obrata od metafizičkog (str. 12). Augustin razrješenje daje kroz fundiranje nelagode/uznemirenosti u još dubljem padu, otu- 